\title{
GENE EXPRESSION ANALYSIS: A WAY TO STUDY TOLERANCE TO ABIOTIC STRESSES IN CROPS SPECIES
}

\author{
Eduardo Pérez-Torres ${ }^{1 *}$, Mario Paredes C. ${ }^{1}$, Víctor Polancoํㅜ, and Viviana Becerra B. ${ }^{1}$
}

\begin{abstract}
Regions traditionally destined to agriculture report an ever increasing exposure to cold and drought conditions. This is especially important in countries like Chile where crop management options are limited. The development of new cultivars with better yields under adverse conditions is fundamental if the ever increasing demand for food is to be matched; however, improving tolerance to abiotic stresses has proved to be a complex task. In this regard, development in plant physiology and genomics in the last 20 years has led to a deeper understanding of how plants respond to stress and mechanisms responsible for different ranges of tolerance observed in nature. This review discusses the techniques currently most in use in gene expression analysis, together with some important experimental design variables, such as the developmental stage of the plant, stress intensity and duration, and how different stresses may interact when performing assays. On the other hand, it is fundamental to properly select gene expression techniques according to the available information on the genome, the crop and the final objective of the research. All these points must be considered to ease transition from genomics to practical applications to crop species in order to increase their tolerance to stress. In this regard, the rapid development of new techniques in gene expression analysis with lower costs will determine a new revolution in crop research in coming decades. Therefore, Chile needs to be prepared in this area to continue its development as a major food producer worldwide.
\end{abstract}

Key words: cold, drought, crops species, gene expression.

\section{INTRODUCTION}

Episodes of low or high temperature and drought are among the environmental conditions that most plants experience on a daily basis. In crops, this variation from ideal growth conditions often results in lower yields and a high economic impact for producers and consumers.

Understanding the mechanisms involved in the response of plants to adverse environmental conditions is, without a doubt, the first step in the generation of crops with higher tolerance to stress. Research at the level of genes (genomics), proteins (proteomics), metabolites (metabolomics), individuals (physiology, systemic- biology) and communities (ecology) has been fundamental in the current understanding of the response of plants to stress. In particular, a huge development in the field of genomics in the last 20 years has led to a deeper understanding in areas such as gene expression, organization and its relationship to stress tolerance. Functional genomics studies the function of genes of an organism and focuses

${ }^{1}$ Instituto de Investigaciones Agropecuarias, Centro Regional de Investigación Quilamapu, Casilla 426, Chillán, Chile.

*Corresponding author (eperez@inia.cl).

Received: 12 May 2008.

Accepted: 14 August2008. on dynamic processes such as transcription, translation, interaction of genes and how they are related to different phenotypes. Connecting gene function and traits relevant to agriculture, such as yield, plant structure and tolerance to adverse environmental conditions has become of utmost interest considering global warming, urban development and an ever increasing population demand for food.

Genome analysis has been mostly limited to model plants that fulfil some specific requirements such as: (1) small genome size, (2) short generation time, (3) small size to enable growth in limited space, and (4) availability of gene manipulation technologies (Tabata, 2002). In particular, two of the most important model species are Arabidopsis thaliana and rice (Oryza sativa L.) for dicotyledonous and monocotyledoneous plant species, respectively. Besides its importance as a crop, rice has a high degree of synteny with genomes of other cereals plants, such as maize, wheat, barley and other grasses because their genomes share a considerable similarity in their organization, as well as sequence similarity (Gale and Devos, 1998; Bowers et al., 2005; Paterson et al., 2005). Great advances in the comparison of genomes and transcriptomes of different organisms have contributed to the development of comparative genomics as one of the most promising fields in the area (Gale and Devos, 1998; 
Caicedo and Purugganan, 2005). In this way, finding variations in the genome or the transcriptome from the current model species related to interesting agronomic traits is of the highest importance for crop biotechnology (van de Mortel and Aarts, 2006).

The objective of this review is to summarize current techniques used in gene expression analysis in plants and their relevance to abiotic stress research. Special emphasis is given to issues to be considered when comparing performance of crops in controlled conditions and in the field.

\section{Techniques used for evaluating gene expression in functional genomics studies}

A fundamental step in any functional genomics study is the analysis of gene expression. One of the greatest strengths of genomics compared to other disciplines is the prospect of analyzing the expression of thousands of genes simultaneously, resulting in a more comprehensive picture of changes occurring in the transcriptome across different conditions (Green et al., 2001).

The technology available for the analysis of gene expression can be divided into two categories: closed and open systems (Table 1). Closed systems are characterized by a finite number of genes that can be assessed by virtue of their inclusion by selection. Therefore, the coverage of genes will be related to the completeness of the knowledge of the genome being studied, limiting this kind of analysis to the most well characterized species or systems (Green et al., 2001). Typically, closed systems such as microarrays (Table 2) and real-time polymerase chain reaction (PCR) have been extensively used in gene expression analysis in plants (Ma et al., 2005; Rensink et al., 2005; Oono et al., 2006; Xu and Shi, 2006; Mantri et al., 2007; Monroy et al., 2007; Fernandez et al., 2008; Remans et al., 2008). On the other hand, with open systems there is no need for previous knowledge of the genome or transcriptome of the organism. cDNA-AFLP (cDNA-Amplified fragment length polymorphism), MPSS (massively parallel signature sequencing), and specially SAGE (serial analysis of gene expression) have been successfully used to quantify transcript abundance and generate expression data across different tissue types or developmental stages in higher plants ( Fizames et al., 2004; Meyers et al., 2004; Calsa and Figueira, 2007; Chen et al., 2007; Leymarie et al., 2007; McIntosh et al., 2007; Song et al., 2007; Ritter et al., 2008). Worth mentioning are 454-sequencing technology and digital gene expression (DGE) that have recently been used to study the transcriptome of different organisms and promise to become an efficient and costeffective alternative with high potential in crop research (Mikkilineni et al., 2004; Margulies et al., 2005; Velculescu and Kinzler, 2007; Weber et al., 2007; Torres et al., 2008). Open and closed systems should not be considered as competitors, but rather as complementary technologies to

\section{Table 1. Most commonly used techniques for gene expression analysis in plants.}

cDNA-AFLP. RNA is converted into double stranded cDNA and then digested with two restriction enzymes: a frequent-cutter and a rare-cutter. Synthetic adapters are ligated to the cDNA ends and primers complementary to the adapter sequences (plus small extensions of 1, 2, or 3 nucleotides) are used to amplify fragments with asymmetric ends. These fragments are displayed on sequencing gels and compared. Specific fragments can be eluted from gels and sequenced to identify genes with differential expression (Bachem et al., 1996).

SAGE. RNA is converted to double-stranded cDNA with a biotin attached to the oligo(dT) first strand synthesis primer and cleaved with a restriction enzyme, leaving 3'-most fragments immobilized onto streptavidin beads. After ligation with linkers onto the non-biotinylated end cDNAs are released, ligated together and amplified by PCR. Primer regions are removed from PCR products and the resulting fragments are ligated together into concatemers, cloned and sequenced. Finally, a software package identifies and counts the relative frequency of the sequences in the samples (Velculescu et al., 1995; Yamamoto et al., 2001).

MPSS. Individual 3' restriction fragments from a cDNA library are coupled to one of a million beads, amplified, arrayed and sequenced simultaneously for 20 residues to provide a million signature sequences. Transcripts can then be identified and the corresponding transcriptome quantitatively characterized (Brenner et al., 2000).

Microarrays. Marked samples are tested against sequences from thousands of different genes fixed on small solid supports (usually glass microscope slides). Depending on their sequence, the samples will hybridize with different spots in the array, which is analyzed by specialized image software (Schena et al., 1995).

Real-time PCR. A variant from conventional PCR based on the detection and quantification of the fluorescence emitted by PCR products accumulated through the amplification process (Higuchi et al., 1993). 
be used depending on the subject to be analyzed and the objectives of the research.

The amount of material available is an important variable to be considered in the selection of a technology for gene expression analysis. In particular, the sensitivity and coverage of the method will be determinant considering that $90-95 \%$ of all mRNA species are present at five or fewer copies per cell (Green et al., 2001). When insufficient quantities of RNA are obtained, cDNA generated from RNA can be amplified exponentially by PCR, or linearly with T7 RNA polymerase to avoid differential amplification (Brady et al., 2006).

Another variable to keep in mind is the selection of the sample to be analyzed. In this regard, the latest advances in microdissection techniques allow extraction of RNA from specific tissues and individual cells, opening the possibility of a highly detailed analysis and a considerable reduction of noise generated by the natural heterogeneity of plant organs (Brandt, 2005; Lee et al., 2005; Ohtsu et al., 2007).

\section{Abiotic stress variables to be considered in functional genomics studies}

The aim of most functional genomics studies concerned with abiotic stress is to relate gene function to traits of plant performance under adverse environmental conditions.
A recurring question is how representative are growth chamber studies compared to field studies. In this respect there is a lack of studies that comprehensively evaluate correlations between growth chambers and the field in terms of plant performance. The issues in what follows should be considered when designing an experiment in controlled conditions with possible applications in the field:

Combination of stresses. Most studies so far have been focused on the response to just one kind of stress. This strategy has led to key discoveries that otherwise would not have been possible and that have helped us to understand in greater depth the way plants respond to stress. However, it should be noted that plants in the field are usually exposed to more than one stress simultaneously. This combination of stresses is fundamental to understand differences between the performance of crops in controlled growth chambers and in the field (Knight and Knight, 2001; Mittler, 2006).

Length of the treatment. Despite the fact that valuable data can be obtained from short term experiments, it is longer term plant performance with respect to biomass, yield data and the degree of recovery from stress that has the most value in agriculture (Vinocur and Altman, 2005).

Table 2. Gene expression analysis through microarrays in some crops.

\begin{tabular}{|c|c|c|}
\hline Plant & Stress & Reference \\
\hline Capsicum annuит & Cold stress & Hwang et al., 2005 \\
\hline Hordeum vulgare & Drought and salinity & Ozturk et al., 2002 \\
\hline \multirow[t]{6}{*}{ Oryza sativa } & Cold, drought, salinity and $\mathrm{ABA}^{1}$ treatment & Rabbani et al., 2003 \\
\hline & Chilling stress & Yamaguchi et al., 2004 \\
\hline & Drought stress & Hazen et al., 2005 \\
\hline & Drought stress & Lan et al., 2005 \\
\hline & Drought stress & Wang et al., 2007 \\
\hline & Drought and high salinity & Zhou et al., 2007 \\
\hline Solanum tuberosum & Cold, heat and salt stress & Rensink et al., 2005 \\
\hline Sorghum bicolor & Dehydration, salt and ABA treatment & Buchanan et al., 2005 \\
\hline \multirow[t]{2}{*}{ Triticum aestivum } & Low-temperature stress & Gulick et al., 2005 \\
\hline & Drought & Mohammadi et al., 2007 \\
\hline Helianthus annuus & Chilling stress & Fernandez et al., 2008 \\
\hline Zea mays & Salinity & Wang et al., 2003 \\
\hline Manihot esculenta & Heat and drought & Sakurai et al., 2007 \\
\hline
\end{tabular}

\footnotetext{
${ }^{1}$ ABA: amino butyric acid.
} 
Intensity of the treatment. Plants respond in different manners to variable degrees of stress, as different protection/repair mechanisms will be engaged accordingly. For example, the response of a plant to chilling stress will be different from the response to freezing stress, considering that the latter can lead to ice formation. The intensity of the treatment will also be of the utmost importance for screening purposes, especially when a ranking of tolerance to stress is to be established.

Stage of crop development. Clearly, tolerance to stress is different throughout the lifecycle of any plant and the consequences of exposure to stress may also vary. As an example, rice is especially susceptible to low temperature during the germination and reproductive stages (Board et al., 1980; Jacobs and Pearson, 1994) In the first, a possible consequence is the failure to germinate. Exposure to cold during the reproductive stage will induce sterility rather than have an effect on plant survival. In this regard, it is important to have plants in similar stages of development when screening for tolerance to stress, especially with cultivars that complete their lifecycle at different times.

Designing experiments in functional crop genomics must consider all these recommendations in order to successfully extrapolate results to the field. As well, it is important to keep in mind genotype $\mathrm{x}$ environment interactions ( $\mathrm{G} \times \mathrm{E}$ ) when evaluating the performance of any genotype in the field by including the range of adaptation of new varieties to different environments and the consistency of their performance over time. In order to effectively recognize $\mathrm{G} \times \mathrm{E}$ in any breeding program, there must be a comprehensive characterization of the genotypes and environments being assayed, and these considerations are valid for genomics as well.

\section{Functional genomics and stress response in crops}

Abiotic stresses are estimated to reduce yield to less than half compared to the potential under ideal growing conditions (Boyer, 1982). Unlike plant resistance to biotic stresses, which is mostly monogenic, tolerance to abiotic stresses are generally multigenic, quantitative and complex traits controlled by quantitative trait loci (QTL). This has clear consequences for the development of plants that are more tolerant to abiotic stresses by genetic engineering (Vinocur and Altman, 2005). A further complication is that some genes may exert control over different traits, resulting in unwanted changes in agronomic plant traits.

Cold and drought tolerance in crops constitute highly desired traits in Chile given the economic consequences of the current climatic trend of very low temperatures in winters and severe drought in summers. Cold stress in plants causes a reduction in enzyme activities, reaction rates, energy imbalance and is accompanied by changes in the transcriptome, proteome and metabolome (Guy et al., 2008). On the other hand, when plants are exposed to drought, there is a characteristic response of a partialto-total stomatal closure, resulting in a reduction of $\mathrm{CO}_{2}$ uptake, transpiration and a major impact for photosynthesis and source-sink relationships (Chaves et al., 2002).

The consequences of any stress will depend on its intensity. As an example, chilling temperatures will be responsible for lower metabolic rates and energy imbalance, while freezing temperatures will additionally cause membrane injury and severe dehydration when ice forms (Graham and Patterson, 1982; Thomashow, 1998; Pearce, 2001).

Drought and temperature stress might occur alone or in combination at any stage in plant development, causing reduced grain weight and yield loss (Sreenivasulu et al., 2007). It is known that exposure to one kind of stress usually involves an increased tolerance to other stresses given that similar effects are shared at the cellular level. As an example, freezing temperatures, low water availability and high salinity can all cause lowering of the cellular osmotic potential and thereby activate osmotic stress responses (Langridge et al., 2006). In this regard, it is not unexpected to find promoters that have sequences for transcription factors involved in drought, salt and cold response, suggesting points of convergence at the molecular level (Knight and Knight, 2001). These results, added to a high overlapping of genes involved in the response to cold, drought and high salinity, suggest an intricate coordination of the response to multiple stresses in plants at molecular level (Kreps et al., 2002; Seki et al., 2002; Seki et al., 2004; Matsui et al., 2008).

At first glance, a shared regulatory network involved in the response to multiple stresses opens possibilities for the development of multiple-stress-tolerant plants. However, it must not be forgotten that the combination of some stresses might require conflicting or antagonistic responses. In this way, the acclimation of plants to this combination would require an appropriate response to each individual stress, as well as compensation and adjustment for some of the antagonistic aspects involved (Mittler, 2006; Rizhsky et al., 2004). As an example, when plants are exposed to drought, their stomata are closed, which is clearly an antagonistic response if the plant is simultaneously exposed to heat, when transpiration is necessary to reduce leaf temperature.

Higher tolerance to abiotic stress could be achieved by increasing protective mechanisms (antioxidants, nonphotochemical quenching, etc.) or by increasing the capacity to repair the damage caused by stress. In this matter, the capacity of recovery from stress is usually overlooked, despite its relevance considering that cycles of stress and recovery are common under natural 
conditions and may have a major impact in yield (Vinocur and Altman, 2005).

In model species, such as Arabidopsis, more than $40-50 \%$ of identified stress-responsive gene functions remains to be characterized (Sreenivasulu et al., 2007). In this regard, a successful approach in determining gene function comes from sequence comparison with databases and, more recently, the use of coexpression modules with promising results (Subramanian et al., 2005).

Comparative genomics constitute an increasingly important field in order to understand how similar model species and crops are, and how to transfer knowledge obtained from model species to applications in agriculture (Paterson et al., 2005; van de Mortel and Aarts, 2006). In this matter, the choice of putative candidate genes is facilitated by the conservation of gene sequences, order and distribution among species and the existence of similar functional gene categories in morphologically similar organs (Brady et al., 2006; Pflieger et al., 2001).

Changes in the transcriptome among related species under stress reported by different groups are usually hard to compare since treatments are usually performed with different tissues, exposure times, intensities, and using different technologies. In this way, a careful experimental design with related plants that present different degrees of tolerance to stress can be extremely informative. A successful example is the comparison of the transcriptome of winter and spring wheat, cultivars with different tolerance to cold, exposed to low temperature. This study reports the correlation of gene expression kinetics with tolerance to low temperature, a subject usually overlooked that emphasizes the importance of sampling in functional genomics studies (Gulick et al., 2005; Monroy et al., 2007).

Gene expression profiling has allowed the identification of hundreds of genes induced when plants are exposed to stress ( Kreps et al., 2002; Oono et al., 2006; Jianping and Suleiman, 2007; Mantri et al., 2007). The availability of the complete genome sequence of some model plants, such as $O$. sativa and $A$. thaliana, has allowed the development of whole genome tiling microarrays. This constitutes a new powerful technology that has already made possible the identification of several unannotated transcripts responsive to abiotic stress (Gregory et al., 2008; Matsui et al., 2008). However, finding a gene responsive to stress does not necessarily guarantee its participation in

Table 3. Maize and rice transgenics and stress tolerance.

\begin{tabular}{|c|c|c|c|}
\hline Plant & Gene & Result & Reference \\
\hline \multirow[t]{4}{*}{ Maize } & NPK1 (tobacco MAPKKK) & Drought and freezing tolerance & Shou et al., 2004 \\
\hline & ZmNF-YB2 (maize nuclear factor YB2) & Drought tolerance & Nelson et al., 2007 \\
\hline & ZmPLC1 (phospholipase C 1) & Drought tolerance & Wang et al., 2008 \\
\hline & TsVP (vacuolar-H+-pyrophosphatase) & Drought tolerance & Li et al., 2008 \\
\hline \multirow[t]{14}{*}{ Rice } & HVA1 (Barley group 3 LEA protein) & Drought and salt tolerance & Xu et al., 1996 \\
\hline & GPAT (Arabidopsis glycerol-3P-acyltransferase) & Chilling tolerance & Yokoi et al., 1998 \\
\hline & OsCDPK7 (rice calcium-dependent protein kinase) & $\begin{array}{l}\text { Cold, drought and salt } \\
\text { tolerance }\end{array}$ & Saijo et al., 2000 \\
\hline & Dadc (D. stramonium arginine decarboxylase) & Drought tolerance & Capell et al., 2004 \\
\hline & ABF3 (Arabidopsis ABRE-binding factor 3) & Drought tolerance & Oh et al., 2005 \\
\hline & DREB1A (Arabidopsis DRE-binding protein 1) & Drought and salt tolerance & Oh et al., 2005 \\
\hline & MnSOD (pea Mn superoxide dismutase) & Drought tolerance & Wang et al., 2005 \\
\hline & SNAC1 (rice stress responsive NAC1) & Drought and salt tolerance & Hu et al., 2006 \\
\hline & OsDREB1 (rice DRE-binding protein 1) & $\begin{array}{l}\text { Drought, salt and cold stress } \\
\text { tolerance }\end{array}$ & Ito et al., 2006 \\
\hline & $\mathrm{HvCBF4}$ (barley C-repeat binding factor) & $\begin{array}{l}\text { Drought, salt and cold stress } \\
\text { tolerance }\end{array}$ & Oh et al., 2007 \\
\hline & $\begin{array}{l}\text { OsCIPK03 (rice calcineurin B-like protein- } \\
\text { interacting protein kinase 03) }\end{array}$ & Cold tolerance & Xiang et al., 2007 \\
\hline & $\begin{array}{l}\text { OsCIPK12 (rice calcineurin B-like protein- } \\
\text { interacting protein kinase 12) }\end{array}$ & Drought tolerance & Xiang et al., 2007 \\
\hline & OsTPP1 (trehalose-6-phosphate phosphatase) & Salinity and cold tolerance & Ge et al., 2008 \\
\hline & ZFP252 (rice TFIIIA-type zinc finger protein) & Drought and salt tolerance & Xu et al., 2008 \\
\hline
\end{tabular}


tolerance to this condition. Identification and sequencing allow assigning a putative function to a sequence when a significant homology with genes of known function is found. These results are then usually complemented with a proper validation by the use of transgenics. This approach has been especially important in the discovery of several candidate genes in crops in the last decade and, in some cases, it has led to significant improvements in tolerance to stress (Table 3). As an example, the relevance of membrane lipids in tolerance to cold was shown in rice transformed with Arabidopsis glycerol3P-acyltransferase (GPAT) that increased the levels of unsaturated fatty acids in the phosphatidylglycerol by $28 \%$ and resulted in a $20 \%$ increase in the photosynthetic rates at $17^{\circ} \mathrm{C}$ (Yokoi et al., 1998). An example showing the importance of transcription factors in the response to stress was observed in transgenic rice for the transcription factor ABF3 (Arabidopsis ABRE-binding factor 3), which showed increased tolerance to drought (Oh et al., 2005).

It is also interesting that different responses are obtained by manipulation of genes within the same family. A good example are calcineurin B-like protein-interacting protein kinases: OsCIPK03, OsCIPK12, and OsCIPK15, whose over-expression in japonica rice Zhonghua, led to specific improved tolerance to cold, drought, and salt stress respectively (Xiang et al., 2007). These results demonstrate the participation of single genes in tolerance to a particular stress. However, it has also been shown that manipulation of single genes can lead to increased tolerance to more than one kind of stress. As an example, the constitutive expression of the transcription factor DREB1A (Arabidopsis DRE-binding protein 1) in rice determined increased tolerance to drought and salt stress. Interestingly, when OsDREB1 (rice DRE-binding protein 1) was over-expressed in rice it resulted in increased tolerance for drought, salt and cold stress (Ito et al., 2006). Similar multi-tolerance effects were observed by over-expressing genes such as OsCDPK7, a calciumdependent protein kinase, which resulted in rice with increased tolerance to cold, salt and drought stress (Saijo et al., 2000). Manipulation of genes with roles other than regulation, such as detoxification, protection and osmotic regulation, has also resulted in increased tolerance to stress in plants (Xu et al., 1996; Capell et al., 2004; Ge et al., 2008; Li et al., 2008; Wang et al., 2008). Targeting effector, rather than regulatory genes, may result in fewer side effects considering the unwanted activation of responsive genes involved in other metabolic pathways.

Despite similarities among different plants, it must not be forgotten that species such as wheat and barley, with far less characterized genomes compared to model plants, may offer unique and interesting features. Their high level of abiotic tolerance and diversity may provide important resources for validation of candidate genes and accelerate important breeding programs (Langridge et al., 2006). Performance in the field of these species suggests that greater tolerance to abiotic stress is still achievable for other crops if proper research is conducted and should stimulate the exploration of new technologies and alliances between scientists and farmers.

\section{CONCLUSIONS}

Gene expression profiling constitutes an exciting tool to unveil mechanisms involved in the response of plants to environmental stress. Its application in crop research is just starting as technologies are becoming more accessible and cost-effective and are expected to fuel huge advances in agriculture in the coming decades. Currently, the importance of biotechnology is being acknowledged by breeding programs around the world and is resulting in the development of new techniques and approaches to increase crop tolerance to stress. Whether Chile will continue to increase its share in the food market worldwide will depend on its ability to develop sustainable and cutting-edge crop research in the future.

\section{RESUMEN}

Análisis de la expresión génica: Una forma de estudiar la tolerancia a estreses abióticos en cultivos. Las regiones agrícolas están cada vez más expuestas a condiciones de frío y sequía, algo especialmente importante en países con opciones limitadas de manejo de cultivos como Chile. Si la creciente demanda por alimento ha de ser cubierta, es necesaria la compleja tarea del desarrollo de nuevos cultivares con mejores rendimientos bajo condiciones de estrés. El desarrollo de la fisiología vegetal y la genómica en los últimos 20 años ha permitido entender mejor cómo las plantas responden al estrés y los mecanismos responsables de los distintos rangos de tolerancia observados en la naturaleza. En esta revisión, se discuten las técnicas más usadas actualmente en análisis de expresión génica $\mathrm{y}$ algunas variables que deben ser consideradas en el diseño experimental tales como el estado de desarrollo de la planta y la intensidad, duración e interacción de distintos tipos de estrés, además de la elección de técnicas apropiadas de acuerdo a la información disponible del genoma del cultivo y el objetivo final de la investigación. Todos estos puntos son fundamentales para facilitar la transición desde la genómica a aplicaciones prácticas en el aumento de la tolerancia al estrés de los cultivos. En este sentido, el rápido desarrollo de nuevas técnicas para estudiar la expresión de genes a menor costo determinará una nueva revolución en la investigación de cultivos en 
las próximas décadas. En este sentido, Chile necesita estar preparado en esta área para continuar su desarrollo como un importante productor de alimentos a nivel mundial.

Palabras clave: frío, sequía, cultivos, expresión génica.

\section{LITERATURE CITED}

Bachem, C.W.B., R.S. van der Hoeven, S.M. de Bruijn, D. Vreugdenhil, M. Zabeau, and R.G.F. Visser. 1996. Visualization of differential gene expression using a novel method of RNA fingerprinting based on AFLP: Analysis of gene expression during potato tuber development. Plant J. 9:745-753.

Board, J.E., M.L. Peterson, and E. Ng. 1980. Floret sterility in rice in a cool environment. Agron. J. 72:483-487.

Bowers, J.E., M.A. Arias, R. Asher, J.A. Avise, R.T. Ball, G.A. Brewer, et al. 2005. Comparative physical mapping links conservation of microsynteny to chromosome structure and recombination in grasses. Proc. Natl. Acad. Sci. USA. 102:13206-13211.

Boyer, J. 1982. Plant productivity and environment. Science 218:443-448.

Brady, S.M., T.A. Long, and P.N. Benfey. 2006. Unraveling the dynamic transcriptome. Plant Cell 18:2101-2111.

Brandt, S.P. 2005. Microgenomics: gene expression analysis at the tissue-specific and single-cell levels. J. Exp. Bot. 56:495-505.

Brenner, S., M. Johnson, J. Bridgham, G. Golda, D.H. Lloyd, D. Johnson, et al. 2000. Gene expression analysis by massively parallel signature sequencing (MPSS) on microbead arrays. Nat. Biotechnol. 18:630-634.

Buchanan, C.D., S. Lim, R.A. Salzman, I. Kagiampakis, D.T. Morishige, B.D. Weers, et al. 2005. Sorghum bicolor's transcriptome response to dehydration, high salinity and ABA. Plant Mol. Biol. 58:699-720.

Caicedo, A.L., and M.D. Purugganan. 2005. Comparative plant genomics. Frontiers and prospects. Plant Physiol. 138:545-547.

Calsa, T., and A. Figueira. 2007. Serial analysis of gene expression in sugarcane (Saccharum spp.) leaves revealed alternative C4 metabolism and putative antisense transcripts. Plant Mol. Biol. 63:745-762.

Capell, T., L. Bassie, and P. Christou. 2004. Modulation of the polyamine biosynthetic pathway in transgenic rice confers tolerance to drought stress. Proc. Natl. Acad. Sci. USA. 101:9909-9914.

Chaves, M.M., J.S. Pereira, J. Maroco, M.L. Rodrigues, C.P.P. Ricardo, M.L. Osorio, et al. 2002. How plants cope with water stress in the field? Photosynthesis and growth. Ann. Bot. London 89:907-916.
Chen, J., V. Agrawal, M. Rattray, M. West, D. St Clair, R. Michelmore, et al. 2007. A comparison of microarray and MPSS technology platforms for expression analysis of Arabidopsis. BMC Genomics 8:414.

Fernandez, P., J.D. Rienzo, L. Fernandez, H.E. Hopp, N. Paniego, and R.A. Heinz. 2008. Transcriptomic identification of candidate genes involved in sunflower responses to chilling and salt stresses based on cDNA microarray analysis. BMC Plant Biol. 8:11.

Fizames, C., S. Munos, C. Cazettes, P. Nacry, J. Boucherez, F. Gaymard, et al. 2004. The arabidopsis root transcriptome by serial analysis of gene expression. Gene identification using the genome sequence. Plant Physiol. 134:67-80.

Gale, M.D., and K.M. Devos. 1998. Comparative genetics in the grasses. Proc. Natl. Acad. Sci. USA. 95:19711974.

Ge, L.-F., D.-Y. Chao, M. Shi, M.-Z. Zhu, J.-P. Gao, and H.-X. Lin. 2008. Overexpression of the trehalose-6phosphate phosphatase gene OsTPP1 confers stress tolerance in rice and results in the activation of stress responsive genes. Planta 228:191-201.

Graham, D., and B.D. Patterson. 1982. Responses of Plants to low, nonfreezing temperatures: proteins, metabolism, and acclimation. Annu. Rev. Plant Physiol. Plant Mol. Biol. 33:347-372.

Green, C.D., J.F. Simons, B.E. Taillon, and D.A. Lewin. 2001. Open systems: panoramic views of gene expression. J. Immunol. Methods 250:67-79.

Gregory, B.D., J. Yazaki, and J.R. Ecker. 2008. Utilizing tiling microarrays for whole-genome analysis in plants. Plant J. 53:636-644.

Gulick, P.J., S. Drouin, Z. Yu, J. Danyluk, G. Poisson, A.F. Monroy, and F. Sarhan. 2005. Transcriptome comparison of winter and spring wheat responding to low temperature. Genome 48:913-923.

Guy, C., F. Kaplan, J. Kopka, J. Selbig, and D.K. Hincha. 2008. Metabolomics of temperature stress. Physiol. Plant 132:220-235.

Hazen, S.P., M.S. Pathan, A. Sanchez, I. Baxter, M. Dunn, B. Estes, et al. 2005. Expression profiling of rice segregating for drought tolerance QTLs using a rice genome array. Funct. Integr. Genomics 5:104-116.

Higuchi, R., C. Fockler, G. Dollinger, and R. Watson. 1993. Kinetic PCR analysis: Real-time monitoring of DNA amplification reactions. Nat. Biotechnol. 11:1026-1030.

Hu, H., M. Dai, J. Yao, B. Xiao, X. Li, Q. Zhang, and L. Xiong. 2006. Overexpressing a NAM, ATAF, and CUC (NAC) transcription factor enhances drought resistance and salt tolerance in rice. Proc. Natl. Acad. Sci. USA. 103:12987-12992. 
Hwang, E.-W., K.-A. Kim, S.-C. Park, M.-J. Jeong, M.O. Byun, and H.-B. Kwon. 2005. Expression profiles of hot pepper (Capsicum annuum) genes under cold stress conditions. J. Biosci. 30:657-667.

Ito, Y., K. Katsura, K. Maruyama, T. Taji, M. Kobayashi, M. Seki, et al. 2006. Functional analysis of rice DREB1/CBF-type transcription factors involved in cold-responsive gene expression in transgenic rice. Plant Cell Physiol. 47:141-153.

Jacobs, B.C., and C.J. Pearson. 1994. Cold damage and development of rice: a conceptual model. Aust. J. Exp. Agric. 34:917-919.

Jianping, P.W., and S.B. Suleiman. 2007. Monitoring of gene expression profiles and identification of candidate genes involved in drought responses in Festuca mairei. Mol. Genet. Genomics 277:571-587.

Knight, H., and M.R. Knight. 2001. Abiotic stress signalling pathways: specificity and cross-talk. Trends Plant Sci. 6:262-7.

Kreps, J.A., Y. Wu, H.-S. Chang, T. Zhu, X. Wang, and J.F. Harper. 2002. Transcriptome changes for arabidopsis in response to salt, osmotic, and cold stress. Plant Physiol. 130:2129-2141.

Lan, L., M. Li, Y. Lai, W. Xu, Z. Kong, K. Ying, et al. 2005. Microarray analysis reveals similarities and variations in genetic programs controlling pollination/ fertilization and stress responses in rice (Oryza sativa L.). Plant Mol. Biol. 59:151-164.

Langridge, P., N. Paltridge, and G. Fincher. 2006. Functional genomics of abiotic stress tolerance in cereals. Brief. Funct. Genomics Proteomics 4:343354.

Lee, J.-Y., M. Levesque, and P.N. Benfey. 2005. Highthroughput RNA isolation technologies. New tools for high-resolution gene expression profiling in plant systems. Plant Physiol. 138:585-590.

Leymarie, J., E. Bruneaux, S. Gibot-Leclerc, and F. Corbineau. 2007. Identification of transcripts potentially involved in barley seed germination and dormancy using cDNA-AFLP. J. Exp. Bot. 58:425-437.

Li, B., A. We, C. Song, N. Li, and J. Zhang. 2008. Heterologous expression of the TsVP gene improves the drought resistance of maize. Plant Biotech. J. 6:146-159.

Ma, L., C. Chen, X. Liu, Y. Jiao, N. Su, L. Li, et al. 2005. A microarray analysis of the rice transcriptome and its comparison to arabidopsis. Genome Res. 15:12741283.

Mantri, N., R. Ford, T. Coram, and E. Pang. 2007. Transcriptional profiling of chickpea genes differentially regulated in response to high-salinity, cold and drought. BMC Genomics 8:303.
Margulies, M., M. Egholm, W.E. Altman, S. Attiya, J.S. Bader, L.A. Bemben, et al. 2005. Genome sequencing in microfabricated high-density picolitre reactors. Nature 437:376-380.

Matsui, A., J. Ishida, T. Morosawa, Y. Mochizuki, E. Kaminuma, T.A. Endo, et al. 2008. Arabidopsis transcriptome analysis under drought, cold, highsalinity and ABA treatment conditions using a tiling array. Plant Cell Physiol. 49:1135-1149.

McIntosh, S., L. Watson, P. Bundock, A. Crawford, J. White, G. Cordeiro, D. Barbary, L. Rooke, and R. Henry. 2007. SAGE of the developing wheat caryopsis. Plant Biotechnol. J. 5:69-83.

Meyers, B.C., S.S. Tej, T.H. Vu, C.D. Haudenschild, V. Agrawal, S.B. Edberg, et al. 2004. The use of MPSS for whole-genome transcriptional analysis in arabidopsis. Genome Res. 14:1641-1653.

Mikkilineni, V., R.D. Mitra, J. Merritt, J.R. DiTonno, G.M. Church, B. Ogunnaike, and J.S. Edwards. 2004. Digital quantitative measurements of gene expression. Biotechnol. Bioeng. 86:117-124.

Mittler, R. 2006. Abiotic stress, the field environment and stress combination. Trends Plant Sci. 11:15-19.

Mohammadi, M., N.N.V. Kav, and M.K. Deyholos. 2007. Transcriptional profiling of hexaploid wheat (Triticum aestivum L.) roots identifies novel, dehydrationresponsive genes. Plant Cell Environ. 30:630-645.

Monroy, A., A. Dryanova, B. Malette, D. Oren, M. Ridha Farajalla, W. Liu, et al. 2007. Regulatory gene candidates and gene expression analysis of cold acclimation in winter and spring wheat. Plant Mol. Biol. 64:409-423.

Nelson, D.E., P.P. Repetti, T.R. Adams, R.A. Creelman, J. Wu, D.C. Warner, et al. 2007. Plant nuclear factor Y (NF-Y) B subunits confer drought tolerance and lead to improved corn yields on water-limited acres. Proc. Natl. Acad. Sci. USA. 104:16450-16455.

Oh, S.-J., C.-W. Kwon, D.-W. Choi, S.I. Song, and J.-K. Kim, 2007. Expression of barley HvCBF4 enhances tolerance to abiotic stress in transgenic rice. Plant Biotechnol. J. 5:646-656.

Oh, S.-J., S.I. Song, Y.S. Kim, H.-J. Jang, S.Y. Kim, M. Kim, et al. 2005. Arabidopsis CBF3/DREB1A and $\mathrm{ABF} 3$ in transgenic rice increased tolerance to abiotic stress without stunting growth. Plant Physiol. 138:341-351.

Ohtsu, K., H. Takahashi, P.S. Schnable, and M. Nakazono. 2007. Cell type-specific gene expression profiling in plants by using a combination of laser microdissection and high-throughput technologies. Plant Cell Physiol. 48:3-7. 
Oono, Y., M. Seki, M. Satou, K. Iida, K. Akiyama, T. Sakurai, et al. 2006. Monitoring expression profiles of Arabidopsis genes during cold acclimation and deacclimation using DNA microarrays. Funct. Integr. Genomics 6:212-234.

Ozturk, Z.N., V. Talamé, M. Deyholos, C.B. Michalowski, D.W. Galbraith, N. Gozukirmizi, et al. 2002. Monitoring large-scale changes in transcript abundance in drought- and salt-stressed barley. Plant Mol. Biol. 48:551-573.

Paterson, A.H., M. Freeling, and T. Sasaki. 2005. Grains of knowledge: Genomics of model cereals. Genome Res. 15:1643-1650.

Pearce, R.S. 2001. Plant freezing and damage. Ann. Bot. 87:417-424.

Pflieger, S., V. Lefebvre, and M. Causse. 2001. The candidate gene approach in plant genetics: a review. Mol. Breed. 7:275-291.

Rabbani, M.A., K. Maruyama, H. Abe, M.A. Khan, K. Katsura, Y. Ito, et al. 2003. Monitoring expression profiles of rice genes under cold, drought, and highsalinity stresses and abscisic acid application asing cDNA microarray and RNA gel-blot analyses. Plant Physiol. 133:1755-1767.

Remans, T., K. Smeets, K. Opdenakker, D. Mathijsen, J. Vangronsveld, and A. Cuypers. 2008. Normalisation of real-time RT-PCR gene expression measurements in Arabidopsis thaliana exposed to increased metal concentrations. Planta 227:1343-1349.

Rensink, W., S. Iobst, A. Hart, S. Stegalkina, J. Liu, and C. Buell. 2005. Gene expression profiling of potato responses to cold, heat, and salt stress. Funct. Integr. Genomics 5:201-207.

Ritter, E., J. Ruiz de Galarreta, H. van Eck, and I. Sánchez. 2008. Construction of a potato transcriptome map based on the cDNA-AFLP technique. Theor. Appl. Genet. 116:1003-1013.

Rizhsky, L., H. Liang, J. Shuman, V. Shulaev, S. Davletova, and R. Mittler. 2004. When defense pathways collide. The response of Arabidopsis to a combination of drought and heat stress. Plant Physiol. 134:16831696.

Saijo, Y., S. Hata, J. Kyozuka, K. Shimamoto, and K. Izui. 2000. Over-expression of a single $\mathrm{Ca}^{2+}$-dependent protein kinase confers both cold and salt/drought tolerance on rice plants. Plant J. 23:319-327.

Sakurai, T., G. Plata, F. Rodríguez-Zapata, M. Seki, A. Salcedo, A. Toyoda, et al. 2007. Sequencing analysis of 20000 full-length cDNA clones from cassava reveals lineage specific expansions in gene families related to stress response. BMC Plant Biol. 7:66.
Schena, M., D. Shalon, R.W. Davis, and P.O. Brown. 1995. Quantitative monitoring of gene expression patterns with a complementary DNA microarray. Science 270:467-470.

Seki, M., M. Satou, T. Sakurai, K. Akiyama, K. Iida, J. Ishida, et al. 2004. RIKEN Arabidopsis full-length (RAFL) cDNA and its applications for expression profiling under abiotic stress conditions. J. Exp. Bot. 55:213-223.

Seki, M., J. Ishida, M. Narusaka, M. Fujita, T. Nanjo, T. Umezawa, et al. 2002. Monitoring the expression pattern of around 7000 Arabidopsis genes under ABA treatments using a full-length cDNA microarray. Funct. Integr. Genomics 2:282-291.

Shou, H., P. Bordallo, and K. Wang. 2004. Expression of the nicotiana protein kinase (NPK1) enhanced drought tolerance in transgenic maize. J. Exp. Bot. 55:10131019.

Song, S., H. Qu, C. Chen, S. Hu, and J. Yu. 2007. Differential gene expression in an elite hybrid rice cultivar (Oryza sativa, L.) and its parental lines based on SAGE data. BMC Plant Biol. 7:49.

Sreenivasulu, N., S.K. Sopory, and P.B. Kavi Kishor. 2007. Deciphering the regulatory mechanisms of abiotic stress tolerance in plants by genomic approaches. Gene 388:1-13.

Subramanian, A., P. Tamayo, V.K. Mootha, S. Mukherjee, B.L. Ebert, M.A. Gillette, et al. 2005. From the cover: Gene set enrichment analysis: A knowledge-based approach for interpreting genome-wide expression profiles. Proc. Natl. Acad. Sci. USA. 102:1554515550.

Tabata, S. 2002. Impact of genomics approaches on plant genetics and physiology. J. Plant Res. 115:271-275.

Thomashow, M.F. 1998. Role of cold-responsive genes in plant freezing tolerance. Plant Physiol. 118:1-8.

Torres, T.T., M. Metta, B. Ottenwälder, and C. Schlötterer. 2008. Gene expression profiling by massively parallel sequencing. Genome Res. 18:172-177.

van de Mortel, J.E., and M.G.M. Aarts. 2006. Comparative transcriptomics - model species lead the way. New Phytol. 170:199-201.

Velculescu, V.E., and K.W. Kinzler. 2007. Gene expression analysis goes digital. Nat. Biotech. 25:878-880.

Velculescu, V.E., L. Zhang, B. Vogelstein, and K.W. Kinzler. 1995. Serial analysis of gene expression. Science 270:484-487.

Vinocur, B., and A. Altman. 2005. Recent advances in engineering plant tolerance to abiotic stress: achievements and limitations. Curr. Opin. Biotechnol. 16:123-132. 
Wang, C.-R., A.-F. Yang, G.-D. Yue, Q. Gao, H.-Y. Yin, and J.-R. Zhang. 2008. Enhanced expression of phospholipase C 1 (ZmPLC1) improves drought tolerance in transgenic maize. Planta 227:1127-1140.

Wang, F.-Z., Q.-B. Wang, S.-Y. Kwon, S.-S. Kwak, and W.-A. Su. 2005. Enhanced drought tolerance of transgenic rice plants expressing a pea manganese superoxide dismutase. J. Plant Physiol. 162:465-472.

Wang, H., H. Zhang, F. Gao, J. Li, and Z. Li. 2007. Comparison of gene expression between upland and lowland rice cultivars under water stress using cDNA microarray. Theor. Appl. Genet. 115:1109-1126.

Wang, H., S. Miyazaki, K. Kawai, M. Deyholos, D.W. Galbraith, and H.J. Bohnert. 2003. Temporal progression of gene expression responses to salt shock in maize roots. Plant Mol. Biol. 52:873-891.

Weber, A.P.M., K.L. Weber, K. Carr, C. Wilkerson, and J.B. Ohlrogge. 2007. Sampling the arabidopsis transcriptome with massively parallel pyrosequencing. Plant Physiol. 144:32-42.

Xiang, Y., Y. Huang, and L. Xiong. 2007. Characterization of stress-responsive CIPK genes in rice for stress tolerance improvement. Plant Physiol. 144:14161428.

Xu, D., X. Duan, B. Wang, B. Hong, T.H.D. Ho, and R. Wu. 1996. Expression of a late embryogenesis abundant protein gene, HVA1, from barley confers tolerance to water deficit and salt stress in transgenic rice. Plant Physiol. 110:249-257.
Xu, D.-Q., J. Huang, S.-Q. Guo, X. Yang, Y.-M. Bao, H.-J. Tang, and H.-S. Zhang. 2008. Overexpression of a TFIIIA-type zinc finger protein gene ZFP252 enhances drought and salt tolerance in rice (Oryza sativa L.). FEBS Lett. 582:1037-1043.

$\mathrm{Xu}$, W.F., and W.M. Shi. 2006. Expression profiling of the 14-3-3 gene family in response to salt stress and potassium and iron deficiencies in young tomato (Solanum lycopersicum) roots: Analysis by real-time RT-PCR. Ann. Bot. (London) 98:965-974.

Yamaguchi, T., K. Nakayama, T. Hayashi, J. Yazaki, N. Kishimoto, S. Kikuchi, and S. Koike. 2004. cDNA Microarray analysis of rice anther genes under chilling stress at the microsporogenesis stage revealed two genes with DNA transposon castaway in the 5\&prime;-Flanking Region. Biosci. Biotechnol. Biochem. 68:1315-1323.

Yamamoto, M., T. Wakatsuki, A. Hada, and A. Ryo. 2001. Use of serial analysis of gene expression (SAGE) technology. J. Immunol. Methods 250:45-66.

Yokoi, S., S.-I. Higashi, S. Kishitani, N. Murata, and K. Toriyama. 1998. Introduction of the cDNA for shape Arabidopsis glycerol-3-phosphate acyltransferase (GPAT) confers unsaturation of fatty acids and chilling tolerance of photosynthesis on rice. Mol. Breed. 4:269-275.

Zhou, J., X. Wang, Y. Jiao, Y. Qin, X. Liu, K. He, et al. 2007. Global genome expression analysis of rice in response to drought and high-salinity stresses in shoot, flag leaf, and panicle. Plant Mol. Biol. 63:591-608. 